\title{
Kinetics and Thermodynamics of Thermal Inactivation of Cellulase from Salivary Glands of Macrotermes subhyalinus Little Soldier
}

\author{
Fagbohoun Jean Bedel ${ }^{1}$, Yapi Jocelyn Constant ${ }^{2}$, \\ Deffan Zranseu Bénédicte ${ }^{2}$
}

\begin{abstract}
${ }^{1}$ Department of Biochemistry-Genetics, University Peleforo Gon Coulibaly, Korhogo, Côte d'Ivoire ${ }^{2}$ Department on Biochemestry-Microbiologie, University Lorougnon Guede, Daloa, Côte d'Ivoire
\end{abstract}

\begin{abstract}
For optimization of biochemical processes in food and pharmaceutical industries, the evaluation of enzyme inactivation kinetic models is necessary to allow their adequate use. kinetics and thermodynamic analysis of cellulase (GS-CX) from salivary glands of Macrotermes subhyalinus little soldier were studied, using carboxymethylcellulose as a substrate. Optimal conditions for enzymatic studies were determined to be $\mathrm{pH} 5.0$ and $60{ }^{\circ} \mathrm{C}$. Thermal inactivation of GS-CX was examined in more detail between 50 and $65{ }^{\circ} \mathrm{C}$ and in relation to exposure time. The investigation suggests the existence of a non-sensitive heat fraction on the enzyme structure, which is relatively stable up to temperatures close to $55{ }^{\circ} \mathrm{C}$. Denaturation of this enzyme, measured by loss in activity, could be described as a first-order model, with $\mathrm{k}$-values between 0.0052 and $0.0337 \mathrm{~min}^{-1}$. D- and $\mathrm{k}$-values decreased and increased, respectively, with increasing temperature, indicating faster cellulase (GS-CX) inactivation at higher temperatures. Results suggested that GS-CX is a relatively thermostable enzyme with a Z-value of 18.08 ${ }^{\circ} \mathrm{C}$ and $\mathrm{Ea}$ of $115.81 \mathrm{kJmol}^{-1}$. The results of the thermodynamic investigations indicated that the hydrolytic reactions were: (1) not spontaneous $(\Delta \mathrm{G}>0)$ and (2) slightly endothermic $(\Delta H>0)$. Positive values of entropy $(\Delta S>0)$ for GS-CX indicated that this enzyme is found in a chaotic state at the end of the reaction. The high value obtained for the variation in enthalpy indicated that a high amount of energy was required to initiate denaturation, probably due to the molecular conformation of this enzymes. Results shown that the enzyme is quite stable for biotechnological applications.
\end{abstract}

Keywords: Carboxymethylcellulose, Kinetics And Thermodynamic Parameters, Macrotermes Subhyalinus, Thermal Stability, Salivary Glands, Cellulase

\begin{abstract}
Introduction
The major nutritional component for wood-feeding termites is cellulose, which is plant's main structural constituent. Apart from being structural pests, termites have a huge impact on terrestrial ecological processes, as they are part of the main terrestrial cellulose recyclers (Inoue et al., 1997). Cellulase activity in the midgut of these insects is very high (Hogan et al., 1988), and studies have shown that they rely solely on their own cellulases (Slaytor, 1992; Slaytor, 2000) rather than the cellulases of symbiotic bacteria present in their lower intestine (Brune and Stingl, 2005). In nature, cellulose degradation requires the synergistic action of three types of glycoside hydrolases $(\mathrm{GH})$ : endo- $\beta$-1,4glucanases (EG; EC. 3.2.1.4), exo- $\beta$-1, 4cellobiohydrolases (CBH; EC. 3.2.1.91), and $\beta$ glucosidases (EC. 3.2.1.21) (Clarke,1997). Cellulase is a synergistic enzyme that is used to break up cellulose into glucose or other oligosaccharide compounds (Parry et al., 2001). Based on their mode
\end{abstract}

of action, three varieties of cellulase exist which any highly cellulolytic organism must possess (Breznak and Brune 1994). Exoglucanases (EC 3.2.1.91) are the first class of cellulases. The second class of cellulases consists of the endoglucanases (EC 3.2.1.4) while the third class is the beta-glucosidases (EC 3.2.1.21). Cellulases contribute to $8 \%$ of the worldwide industrial enzyme demands (Elba and Maria, 2007). The cellulase market is expected to expand dramatically when cellulases are used to hydrolyzed pretreated cellulosic material to sugars, which can be fermented to bioethanol and biobased products on large scales. Thus, the use of cellulase in various industrial processes is indispensable. It is used in plants and agricultural waste processing (Mswaka and Magan, 1998; Lu et al., 2004), biofuels (Vaithanomsat et al., 2009), triphase biomethanation (Chakraborty et al., 2000), chiral separation and ligand binding studies (Nutt et al., 1998). In addition to this, the major industrial application of cellulases are in textile industry for bio- polishing of fabrics and

This article is published under the terms of the Creative Commons Attribution License 4.0 Author(s) retain the copyright of this article. Publication rights with Alkhaer Publications. Published at: http://www.ijsciences.com/pub/issue/2020-04/

DOI: 10.18483/ijSci.2294; Online ISSN: 2305-3925; Print ISSN: 2410-4477 
producing stonewashed look of denims, as well as in household laundry detergents for improving fabric softness and brightness (Hill et al., 2006). Besides, they are used in animal feeds for improving the nutritional quality and digestibility, in processing of fruit juice and in baking, while de-inking of paper is yet another emerging application. A potential challenging area where cellulases would have a central role is the bioconversion of renewable cellulosic biomass to commodity chemicals (Lynd et al., 2005). Based on the importance of lignocellulosedegrading enzymes, $t$ is necessary to know optimal conditions of enzyme active sites functioning and the effect of different physical-chemical factors on their activity. Hus, any process that enhances the structural stability and reaction rate of enzymes has a favorable impact on their industrial application (Sousa, 1995; Matsumoto et al., 1997). However, there is no report concerning thermal stability of these cellulases. Thus, the knowledge on kinetics of thermal inactivation of cellulase GS-CX is important to allow their suitable utilization as biocatalysts in industry. The present study focus on the investigation of kinetic and thermodynamic parameters of cellulase (GS-CX) from salivary glands of Macrotermes subhyalinus little.

\section{Materials and Methods \\ Enzyme sources}

Little soldiers of the termite Macrotermes subhyalinus were from the savannah of Lamto (Abidjan, Côte d'Ivoire). They were collected directly from their nests and then stored frozen at $20^{\circ} \mathrm{C}$. The cellulase substrate carboxymethylcellulose was obtained from Sigma Chemical Co. (St. Louis, Mo., U.S.A.). All other chemicals and reagents were of analytical grade.

\section{Extraction and purification procedures}

Salivary glands $(10 \mathrm{~g})$ were dissected and homogenized with $20 \mathrm{~mL} 0.9 \% \mathrm{NaCl}(\mathrm{w} / \mathrm{v})$ solution using a blender (Ultra-Turrax) and then sonicated as previously described by Rouland et al. (1988a). The homogenate was centrifuged at 20,000 x g for 15 min. The collected supernatant constituted the crude extract. After freezing at $-180^{\circ} \mathrm{C}$ in liquid nitrogen, the crude extract was stored at $-20^{\circ} \mathrm{C}$ (Kouamé et al., 2005).

The purification procedure was carried out in the cold room $\left(4^{\circ} \mathrm{C}\right)$. The crude extract of the termite salivary glands was loaded onto an anion-exchange chromatography using a DEAE-Sepharose Fast Flow column $(2.5 \mathrm{~cm} \times 4.5 \mathrm{~cm})$, equilibrated with $20 \mathrm{mM}$ sodium acetate buffer ( $\mathrm{pH} 5.0)$. The column was washed at a flow rate of $90 \mathrm{~mL} / \mathrm{h}$ with two bed volumes of equilibration buffer to remove unbound proteins. Bound proteins were then eluted with a stepwise salt gradient $(0.1,0.2,0.4$ and $2 \mathrm{M})$ of $\mathrm{NaCl}$ in $20 \mathrm{mM}$ sodium acetate buffer $(\mathrm{pH} 5.0)$, and fractions of $2 \mathrm{~mL}$ were collected. One peak of enzyme possessing endo-xylanase/endo-cellulase activity was obtained and the active fractions were pooled. The pooled active fractions were loaded onto a cation-exchange chromatography using a CMSepharose CL-6B column $(2.6 \mathrm{~cm}$ x $4.0 \mathrm{~cm})$, equilibrated with $20 \mathrm{mM}$ sodium acetate buffer $(\mathrm{pH}$ 5.0). The column was washed with the same buffer at a flow rate of $90 \mathrm{~mL} / \mathrm{h}$. Cellulase activity was eluted with a stepwise salt gradient $(0.1,0.2,0.4$ and $2 \mathrm{M})$ $\mathrm{NaCl}$ in $20 \mathrm{mM}$ sodium acetate buffer ( $\mathrm{pH} 5.0$ ). Fractions of $2 \mathrm{~mL}$ were collected and, to the pooled active fractions, solid sodium thiosulphate was slowly added to give a final concentration of $1.7 \mathrm{M}$ and the resulting enzyme solution was subsequently applied on a Phenyl Sepharose 6 Fast Flow column $(1.5 \mathrm{~cm} \times 3.2 \mathrm{~cm})$ previously equilibrated with 20 $\mathrm{mM}$ sodium acetate buffer ( $\mathrm{pH}$ 5.0) containing $1.7 \mathrm{M}$ of sodium thiosulphate salt. The column was washed with a reverse stepwise gradient of sodium thiosulphate concentrations (from 1.7-0 M) dissolved in the same sodium acetate buffer at a flow rate of 78 $\mathrm{mL} / \mathrm{h}$ and fractions of $1 \mathrm{~mL}$ were collected. The pooled active fractions were dialyzed overnight against $20 \mathrm{mM}$ sodium acetate buffer (pH 5.0) and constituted the purified enzyme solution.

\section{Enzyme assay and protein determination}

Under the standard test conditions, cellulase activity was assayed spectrophotometrically by measuring the release of reducing sugars from Birchwood carboxyméthylcellulose (CMC). The reaction mixture $(0.38 \mathrm{ml})$ contained $0.2 \mathrm{ml}$ of $0.5 \% \mathrm{CMC}(\mathrm{w} / \mathrm{v})$ dissolved in $20 \mathrm{mM}$ acetate buffer $(\mathrm{pH} 5.0)$ and 0.1 $\mathrm{ml}$ enzyme solution. After $30 \mathrm{~min}$ of incubation at $45^{\circ} \mathrm{C}$, the reaction was terminated by adding $0.3 \mathrm{ml}$ of dinitrosalicylic acid solution followed by $5 \mathrm{~min}$ incubation in a boiling water bath. The product was analysed by measuring the optical density at $540 \mathrm{~nm}$. One unit (U) of enzyme activity was defined as the amount of enzyme capable of releasing one $\mu \mathrm{mol}$ of reducing sugar per min under the defined reaction conditions. Specific activity was expressed as units per $\mathrm{mg}$ of protein (U/mg of protein). Protein concentrations were determined spectrophotometrically at $660 \mathrm{~nm}$ by method of Lowry et al. (1951) using bovine serum albumin as a standard.

\section{Thermal inactivation}

Thermal inactivation of the enzyme was investigated at various constant temperatures from 50 to $65^{\circ} \mathrm{C}$ after exposure to each temperature for a period of 5 to $60 \mathrm{~min}$. The enzyme was heated in sealed tubes, which was incubated in $100 \mathrm{mM}$ sodium acetate buffer ( $\mathrm{pH}$ 5.0) in a thermostatically controlled water 
bath. Tubes were withdrawn at each time intervals and immediately immersed in an ice bath, in order to stop heat inactivation. The residual enzymatic activity, determined in both cases at $37^{\circ} \mathrm{C}$ under the standard test conditions, was expressed as percentage activity of zero-time control of the untreated enzyme.

\section{Kinetic data Analysis}

First-order kinetic has been reported to describe thermal inactivation of cellulase (GS-CX) (Guiavarc'h et al., 2002). The integral effect of inactivation process at constant temperature, where the inactivation rate constant is independent of time, is given in Eq. 1:

$\operatorname{Ln}\left[\mathrm{A}_{\mathrm{t}} / \mathrm{A}_{0}\right]=-\mathrm{kt}$

where;

$A_{t}$ is the residual enzyme activity at time $t(\min )$,

$\mathrm{A}_{0}$ is the initial enzyme activity,

$\mathrm{k}\left(\min ^{-1}\right)$ is the inactivation rate constant at a given condition.

$\mathrm{k}$-values were obtained from the regression line of $\ln$ (At/Ao) versus time as slope.

D-value is defined as the time needed, at a constant temperature, to reduce the initial enzyme activity (Ao) by $90 \%$. For first-order reactions, the D-value is directly related to the rate constant $\mathrm{k}$ (Eq. 2) (Stumbo, 1973; Espachs-Barroso et al., 2006):
$\mathrm{D}=2.303 / \mathrm{k}$
(Eq. 2)

The $\mathrm{Z}$-value $\left({ }^{\circ} \mathrm{C}\right)$ is the temperature increase needed to induce a 10 -fold reduction in D-value (Stumbo, 1973). This Z-value follows the Eq. 3:

$\log \left[\mathrm{D}_{1} / \mathrm{D}_{2}\right]=\left[\mathrm{T}_{2}-\mathrm{T}_{1}\right] / \mathrm{Z}_{\mathrm{T}} \quad$ (Eq. 3)

where,

$\mathrm{T} 1$ and $\mathrm{T} 2$ are the lower and higher temperatures in ${ }^{\circ} \mathrm{C}$ or $\mathrm{K}$

Then, D1 and D2 are D-values at the lower and higher temperatures in min, respectively.

The Z-values were determined from the linear regression of $\log (\mathrm{D})$ and temperature $(\mathrm{T})$.

\section{Thermodynamic Analysis}

The Arrhenius equation is usually utilized to describe the temperature effect on the inactivation rate constants and the dependence is given by (Eq. 4 or 5):
$\mathrm{k}=\mathrm{Ae} \mathrm{e}^{(-\mathrm{E} / \mathrm{RT})}$
(Eq. 4)

Eq. 4 can be transformed to: $\ln \mathrm{k}=\ln \mathrm{A}-\mathrm{Ea} / \mathrm{R} \times \mathrm{T}$. (Eq. 5)

where,

$\mathrm{k}$ is the reaction rate constant value,

A the Arrhenius constant,

Ea $\left(\mathrm{kJ} . \mathrm{mol}^{-1}\right)$ the activation energy,

$\mathrm{R}\left(8.31 \mathrm{~J} . \mathrm{mol}^{-1} \mathrm{~K}^{-1}\right)$ the universal gas constant

$\mathrm{T}$ is the absolute temperature in Kelvin $(\mathrm{K})$.

When the "In" of " $\mathrm{k}$ " is plotted against the reciprocal of the absolute temperature, a linear relationship should be observed in the temperature range studied.
The slope of the line obtained permitted to calculate the activation energy and the ordinate intercept corresponds to ln A (Dogan et al., 2000 and 2002).

The values of the activation energy (Ea) and Arrhenius constant (A) allowed the determination of different thermodynamic parameters (Marin et al., 2003) such as variations in enthalpy, entropy and Gibbs free energy, $\Delta H, \Delta S$ and $\Delta G$, respectively, according to the following expressions (Galani and Owusu, 1997):

$$
\begin{aligned}
& \Delta \mathrm{H}^{\#}=\mathrm{Ea}-\mathrm{RT} \quad \text { (Eq. 6) } \\
& \Delta \mathrm{S}^{\#}=\mathrm{R}\left(\ln \mathrm{A}-\ln \mathrm{K}_{\mathrm{B}} / \mathrm{h}_{\mathrm{P}}-\ln \mathrm{T}\right) \\
& \Delta \mathrm{G}^{\#}=\Delta \mathrm{H}^{\#}-\mathrm{T} \Delta \mathrm{S}^{\#} \quad \text { (Eq. 7) } \\
& \text { Where; }
\end{aligned}
$$

$\mathrm{K}_{\mathrm{B}}$ is the Boltzmann constant $\left(1.38 \times 10^{-23} \mathrm{~J} / \mathrm{K}\right)$, $\mathrm{h}_{\mathrm{P}}$ is the Planck constant $\left(6.626 \times 10^{-34} \mathrm{~J} . \mathrm{s}\right)$,

$\mathrm{T}$ is the absolute temperature.

\section{Statistical Analyses}

All determinations reported in this study were carried out in triplicate. Results were expressed as means \pm standard deviation.

\section{Results and Discussion \\ Kinetic Analysis of Thermal Denaturation}

The optimum temperature of cellulase (GS-CX) purified from salivary glands of Macrotermes subhyalinus little soldier was $60{ }^{\circ} \mathrm{C}$ (Fagohoun et al., 2014). In this study, thermal inactivation of Macrotermes subhyalinus little soldier GS-CX was screened at different temperatures ranged from 50 to $65{ }^{\circ} \mathrm{C}$ by determining the residual enzymatic activity (Table 1). The cellulase (GS-CX) activity was decreased with increasing heating time $(5-60 \mathrm{~min})$ and temperature $\left(50-65^{\circ} \mathrm{C}\right)$. Indeed, at temperatures between 50 and $65^{\circ} \mathrm{C}$, heat-denaturation of cellulase (GS-CX) occurred after 5 min of incubation (97.73 to $85.21 \%$ ). Although heating at $60^{\circ} \mathrm{C}$ for $30 \mathrm{~min}$ resulted in partial $(50.76 \%)$ inactivation. However, a strong inactivation of both enzyme activities was obtained after $60 \mathrm{~min}$ of heat treatment at $65^{\circ} \mathrm{C}$ $(13.53 \%)$. On one hand, the decrease of percentage residual activity at temperatures higher than $50{ }^{\circ} \mathrm{C}$ was most likely due to the unfolding of the tertiary structure of the enzyme to form the secondary structure and on other hand, it could be explained by the chemical modification (Tabatabai 1982). It has been noted that heat stability of the enzyme may be related to molecular forms of enzyme (Zhou and Feng 1991).

The logarithmic linear relationship between the cellulase activity and heat treatment time for the temperature ranged from 50 to $65^{\circ} \mathrm{C}$ followed firstorder kinetics (Figure 1). This result agrees with those reported for cellulase from fungi trichoderma 
Kinetics and Thermodynamics of Thermal Inactivation of Cellulase from Salivary Glands of Macrotermes subhyalinus Little Soldier

viride (Abdul, 2015) and in rice Grasshopper hieroglyphus banian (Haloi et al., 2012)

Table 1: Effect of treatment temperature and time on the inactivation of cellulase from salivary glands of Macrotermes subhyalinus little soldier.

\begin{tabular}{|c|c|c|c|c|c|c|c|c|c|c|c|c|}
\hline \multirow{2}{*}{$\begin{array}{l}\text { Temperature } \\
\left({ }^{\circ} \mathrm{C}\right)\end{array}$} & \multicolumn{12}{|c|}{ Relative activity (\%) at each treatment time (min) } \\
\hline & $5^{*}$ & 10 & 15 & 20 & 25 & 30 & 35 & 40 & 45 & 50 & 55 & 60 \\
\hline \multirow[t]{2}{*}{50} & $97.73 \pm$ & $95.12 \pm$ & $93.24 \pm$ & $86.07 \pm$ & $87.80 \pm$ & $86.07 \pm$ & $83.52 \pm$ & $80.65 \pm$ & $78.89 \pm$ & $77.88 \pm$ & $74.82 \pm$ & $73.34 \pm$ \\
\hline & 0.8 & 1.9 & 1.0 & 0.9 & 0.6 & 1.1 & 0.0 & 0.4 & 0.1 & 0.2 & 0.4 & 0.3 \\
\hline \multirow[t]{2}{*}{55} & $95.12 \pm$ & $91.39 \pm$ & $86.07 \pm$ & $81.06 \pm$ & $76.33 \pm$ & $76.33 \pm$ & $69.07 \pm$ & $66.36 \pm$ & $63.76 \pm$ & $60.04 \pm$ & $57.69 \pm$ & $54.33 \pm$ \\
\hline & 0.6 & 0.9 & 0.4 & 0.4 & 0.2 & 0.6 & 0.3 & 0.7 & 0.7 & 0.2 & 0.7 & 0.2 \\
\hline \multirow[t]{2}{*}{60} & $88.69 \pm$ & $79.45 \pm$ & $69.07 \pm$ & $63.76 \pm$ & $55.98 \pm$ & $50.76 \pm$ & $44.61 \pm$ & $43.07 \pm$ & $38.46 \pm$ & $33.62 \pm$ & $29.81 \pm$ & $27.25 \pm$ \\
\hline & 0.7 & 1.0 & 0.4 & 0.8 & 1.0 & 0.4 & 0.4 & 0.7 & 1.1 & 0.3 & 0.5 & 0.3 \\
\hline \multirow[t]{2}{*}{65} & $85.21 \pm$ & $74.08 \pm$ & $61.26 \pm$ & $49.65 \pm$ & $44.93 \pm$ & $36.78 \pm$ & $31.66 \pm$ & $25.66 \pm$ & $21.22 \pm$ & $18.64 \pm$ & $14.95 \pm$ & $13.53 \pm$ \\
\hline & 0.8 & 1.6 & 0.2 & 1.3 & 0.5 & 0.2 & 0.2 & 0.5 & 1.0 & 0.6 & 0.9 & 0.6 \\
\hline
\end{tabular}

Figure 1: Thermal inactivation curves of cellulase (GS-CX) from salivary glands of Macrotermes subhyalinus little soldier in sodium acetate buffer $(\mathrm{pH} 5.0)$ in the temperature range $50-65^{\circ} \mathrm{C} . \mathrm{A}_{\mathbf{0}}$ is the initial enzymatic activity and $\mathbf{A}_{\mathbf{t}}$ the activity at each holding time. Each data point is the mean of three determinations

\section{Time (min)}

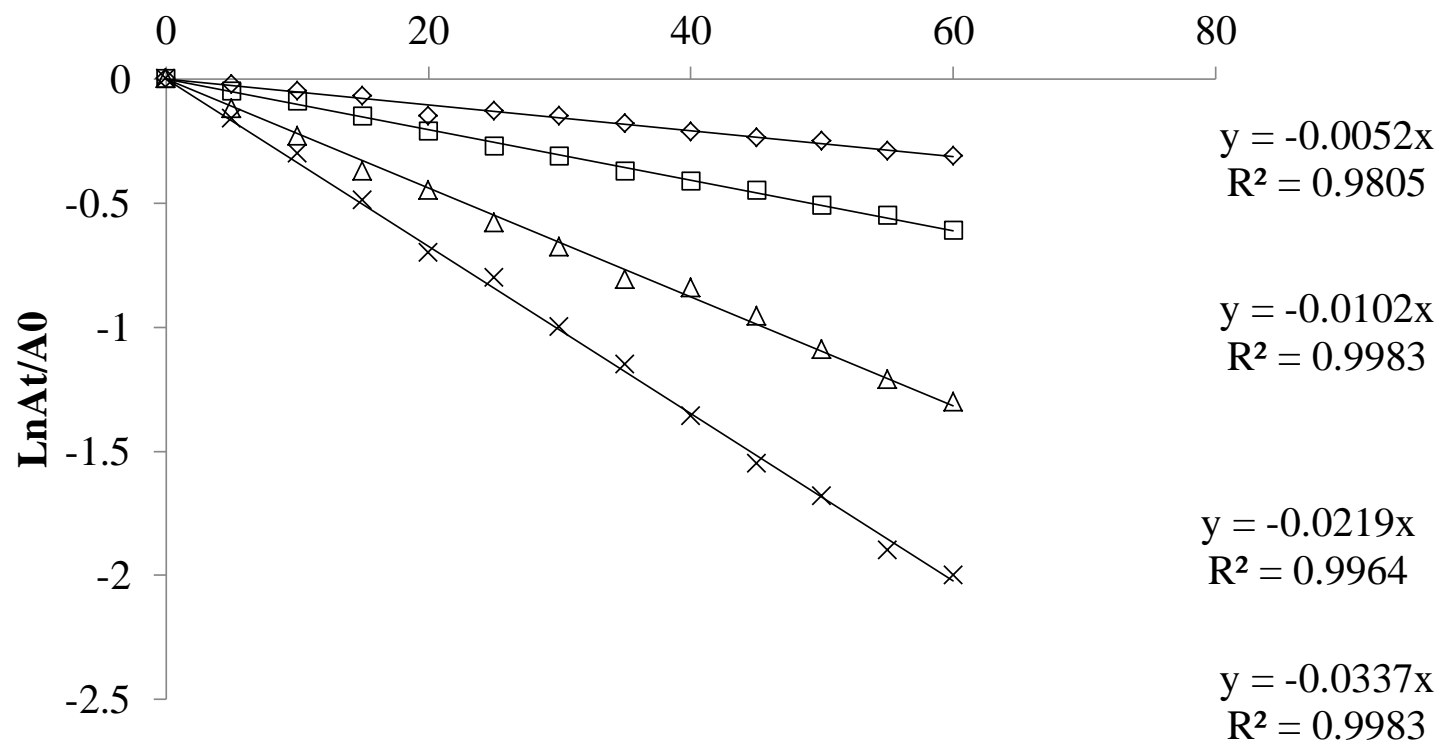

From the slopes of these lines, the inactivation rate constants $(\mathrm{k})$ were calculated and are given in Table 2. The rate constant increased with the heating temperature, indicating that cellulase (GS-CX) from salivary glands of Macrotermes subhyalinus little soldier is less thermostable at higher temperatures $\left(60-65{ }^{\circ} \mathrm{C}\right)$. The dependence of the k-values with temperature was adequately fitted by the Arrhenius equation $\left(\mathrm{R}^{2}=0.990\right)$ (Figure 2$)$. This linearity is an indication that the inactivation in salivary glands GSCX occurs through a unique mechanism dependent on temperature, such as protein unfolding (Gnangui et al., 2009; Waliszewski et al., 2009). 


\section{$\mathbf{1} / \mathbf{T}\left({ }^{\circ} \mathbf{K}-\mathbf{1}\right)$}

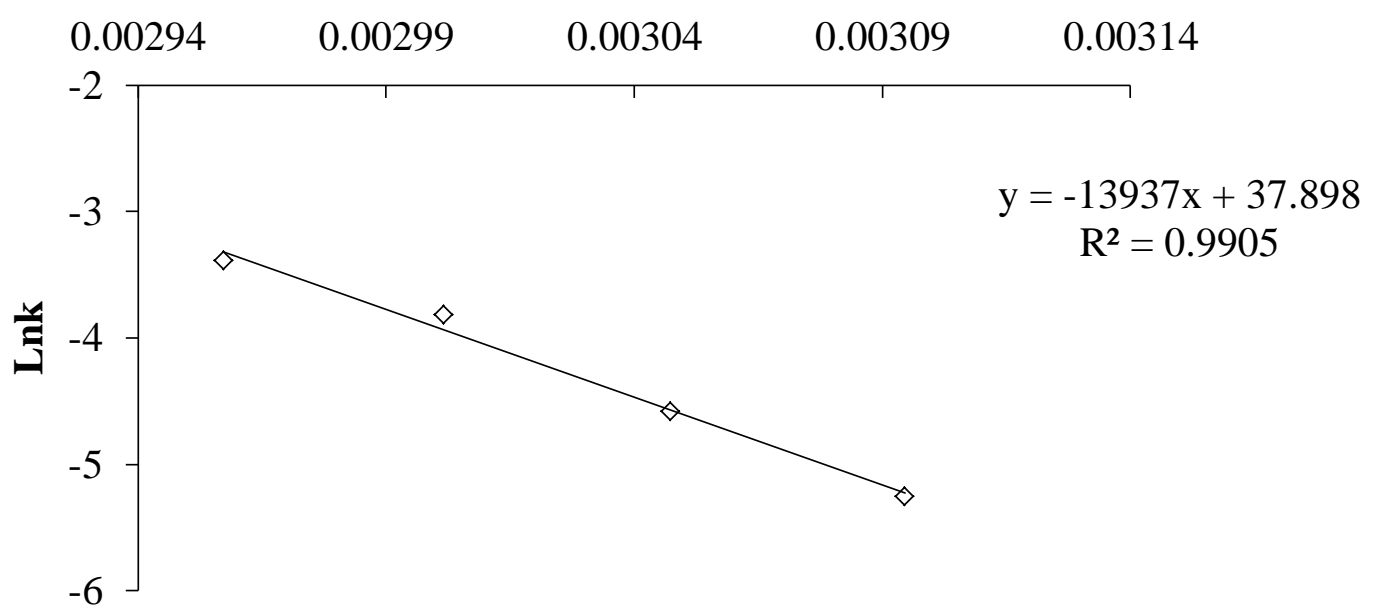

Figure 2: Arrhenius plot showing the effect of temperature on the rate constant for the thermal inactivation of cellulase (GS-CX) from salivary glands of Macrotermes subhyalinus little soldier. 1/T represents the reciprocal of the absolute temperature. Each data point is the mean of three determinations

The half-life $\left(\mathrm{t}_{1 / 2}\right)$ and the decimal reduction time (D-value) are other important parameters commonly used in the characterization of enzyme stability. Increasing the temperature from 50 to $65^{\circ} \mathrm{C}$ resulted in a decrease in $\mathrm{t}_{1 / 2}$ and $\mathrm{D}$-values (Table 2). At the same temperature $\left(65^{\circ} \mathrm{C}\right)$, cellulase (GS-CX) from salivary glands of Macrotermes subhyalinus little soldier $\left(\mathrm{t}_{1 / 2}=20.56 \mathrm{~min}\right)$ was less thermostable than those of other vegetal sources such as exo-PG from pela Linhagem Fungica Thermomucor indicaeseudaticae (t1/2 = $58.3 \mathrm{~min}$ ) (Martin, 2010) and exopolygalacturonase (exo-PG) from Thermophilic Fungus Rhizomucor pusillus $\left(\mathrm{t}_{1 / 2}=96.3 \mathrm{~min}\right)$ (Trindade et al., 2016).

From 50 to $65{ }^{\circ} \mathrm{C}$, the activation energy (Ea) value for thermal inactivation of cellulase (GS-CX) was calculated to be $115.81 \mathrm{~kJ}^{\mathrm{mol}}{ }^{-1}$ (Table 2). High activation energy reflects a greater sensitivity of cellulase to temperature change

(Chutintrasri and Noommhorm 2006). This suggests that the denaturation process requires a high-energy input to the enzyme-substrate complex to initiate denaturation, probably due to a possible compact structure of enzymes and the strength of the thiol groups $(\mathrm{SH})$ or disulfide bond at the active site (Bjorck and Farkye 1992). The Ea-value from salivary glands of Macrotermes subhyalinus little soldier cellulase was much higher than those reported for horseradish cellulase (30.1 kJ.mol-1) and glucose oxydase from horseradish (60.2 kJ.mol-1) (Giannakopoulou et al., 2019), but lower than that for Thermophilic Fungus Rhizomucor pusillus (125.5 kJ.mol-1) (Trindade et al., 2016), exo-PG from A. sojae (286.2 kJ.mol-1) (Dogan and Tari, 2008) and the endoglucanases from A. fumigatus obtained by submerged cultivation (154.7 kJ.mol-1) (Saqib et al., 2010). On this basis, cellulase in salivary glands of Macrotermes subhyalinus little soldier can be classified as heat-sensitive cellulase in terms of inactivation kinetics.

Table 2: $\mathrm{k}, \mathrm{D}-, \mathrm{t}_{1 / 2}, \mathrm{Z}$ - and Ea-values for thermal inactivation of cellulase from salivary glands of Macrotermes subhyalinus little soldier. in the $50-65{ }^{\circ} \mathrm{C}$ temperature range.

\begin{tabular}{|c|c|c|c|c|c|c|}
\hline \multirow{3}{*}{ Temperature $\left({ }^{\circ} \mathrm{C}\right)$} & \multicolumn{6}{|c|}{ Kinetic parameters } \\
\hline & \multicolumn{2}{|c|}{$\mathrm{K}\left(\min ^{-1}\right)$} & \multirow[t]{2}{*}{$\mathrm{D}(\min )$} & \multirow[t]{2}{*}{$t_{1 / 2}(\min )$} & \multirow[t]{2}{*}{$\mathrm{Z}\left({ }^{\circ} \mathrm{C}\right)$} & \multirow[t]{2}{*}{$\mathrm{Ea}(\mathrm{kJ} / \mathrm{mol})$} \\
\hline & Value & $\mathrm{R}^{2}$ & & & & \\
\hline 50 & $0.0052 \pm 0.001^{\mathrm{a}}$ & 0.980 & $442.88 \pm 25$ & $133.27 \pm 8$ & & \\
\hline 55 & $0.0102 \pm 0.002$ & 0.998 & $225.78 \pm 17$ & $67.94 \pm 5$ & $18.08 \pm 0.1$ & $115.81 \pm 0.16$ \\
\hline 60 & $0.0219 \pm 0.001$ & 0.996 & $105.15 \pm 15$ & $31.64 \pm 3$ & & \\
\hline 65 & $0.0337 \pm 0.001$ & 0.998 & $68.33 \pm 17$ & $20.56 \pm 5$ & & \\
\hline
\end{tabular}

(Figure 3) presents the relationship between decimal reduction time and temperature, where the slope of the curve represents $-1 / Z_{\mathrm{T}}$. The estimated value of
Macrotermes subhyalinus little soldier cellulase was $18.08{ }^{\circ} \mathrm{C}\left(\mathrm{R}^{2}=0.9885\right)$. The $\mathrm{Z}$-values for cooking 

subhyalinus Little Soldier

and nutrients degradation $\left(25-45^{\circ} \mathrm{C}\right)$ are generally greater than microbial inactivation $\left(7-12^{\circ} \mathrm{C}\right)$ (Awuah et al., 2007). In fact, differences between the D- and Z-values of enzyme and nutrients are exploited to optimize thermal processes and can be exploited also to maintain carboxymethylcellulase activity after treatment. This indicates that any change in temperature processing affects more intensely the stability of cellulase (GS-CX). In this study, D-, Zand $\mathrm{k}$-values indicate that carboxylmethylcellulase is heat stable and then can be used in high temperature short time and low temperature long time industrial processes such as pasteurization, where values of $65^{\circ} \mathrm{C}$ for $3-5 \mathrm{~min}$ and $55^{\circ} \mathrm{C}$ for $30 \mathrm{~min}$, respectively, are generally considered. In fact, the D- and Z-values of carboxylmethylcellulase is exploited to optimize thermal processes and to preserve enzyme activity after treatment. According to Barrett et al. (1999), high $\mathrm{Z}$-values indicate more sensitivity to the heat treatment time and low $\mathrm{Z}$-values indicate more sensitivity to increasing temperature.

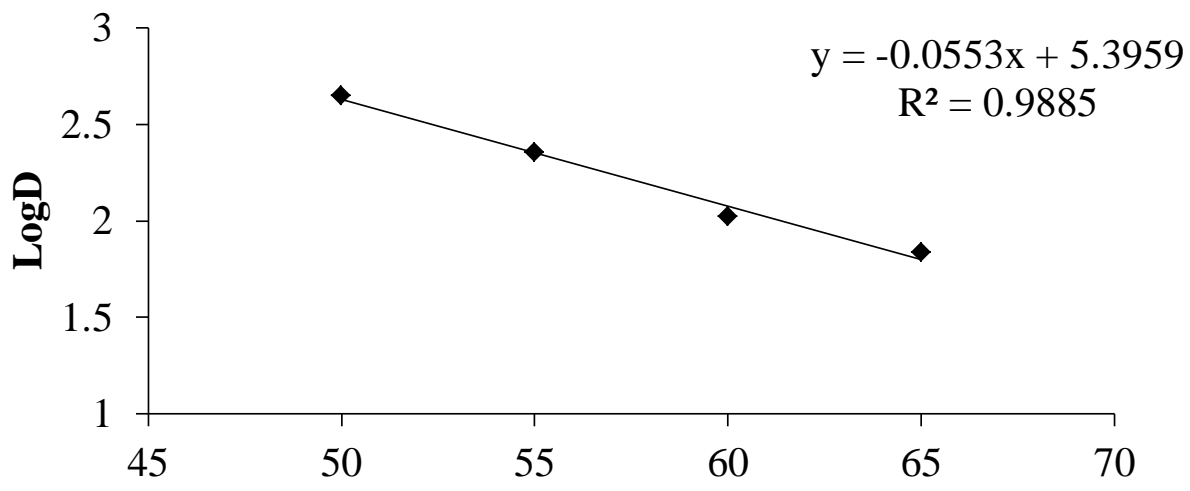

Figure 3: Variation of decimal reduction times with temperature for of cellulase (GS-CX) from salivary glands of Macrotermes subhyalinus little soldier. Each data point is the mean of three determinations

\section{Thermodynamic Analysis of Thermal Denaturation}

The thermodynamic parameters provide information on the enzyme thermal stability for each step of the heat- induced denaturation process. This could help in detecting any secondary stabilization or destabilization effects that would go unnoticed if only the half-life times were considered (Longo and Combes 1999). These parameters include the Gibbs free energy $\left(\Delta G^{\#}\right)$ change considered as the energy barrier for enzyme inactivation, the enthalpy $\left(\Delta \mathrm{H}^{\#}\right)$ change measuring of the number of bonds broken during inactivation, and the entropy $\left(\Delta S^{\#}\right)$ change that indicates the net enzyme and solvent disorder. In this study, they were calculated in the temperature range from 50 to $65^{\circ} \mathrm{C}$ (Table 3 ).

Within the error range of our measurements, results showed that the enthalpy $\left(\Delta \mathrm{H}^{\#}\right)$ is independent of temperature; thus, there is no change in enzyme heat capacity. The $\Delta \mathrm{H}^{\#}$ value of cellulase $\left(89.94 \mathrm{~kJ} . m o l^{-}\right.$ 1 ) was highly than those reported for other cellulase: 23 kJ.mol-1 for horseradish (Giannakopoulou et al., 2019) and 13.4 kJ.mol-1 for fungi trichoderma viride
(Abdul, 2015). The high $\Delta \mathrm{H}^{\#}$ change obtained indicates that cellulase of Macrotermes subhyalinus little soldier undergoes a significant conformational change in order to find in its activated during heat treatment and high amount of energy was required to initiate denaturation, probably due to the molecular conformation of cellulase (GS-CX) (Marin et al., 2003). Positive $\Delta H^{\#}$ values indicate the endothermic nature of the hydrolysis reaction. Our results would therefore suggest that cellulase from salivary glands of Macrotermes subhyalinus little soldier is more structurally robust than the others enzymes.

In contrast, the Gibbs free energy $\left(\Delta \mathrm{G}^{\#}\right)$ value is directly related to protein stability: the higher the $\Delta \mathrm{G}$ is, the higher will be the enzyme stability. Results showed that the $\Delta \mathrm{G}^{\#}$ values the cellulase (GS-CX) slightly increased from $109.36 \mathrm{~kJ}^{-\mathrm{mol}^{-1}}$ to 110.27 $\mathrm{kJ} \mathrm{mol}^{-1}$, when the incubation temperature was elevated $\left(50-65^{\circ} \mathrm{C}\right)$ indicating that the inactivation processes were not spontaneous. Since $\Delta G^{\#}$ decreases with increasing temperature whereas $\Delta \mathrm{H}^{\#}$ is overall constant, one could expect a significant contribution of entropy changes to the thermodynamics of the considered system. Indeed, it was already demonstrated that activation entropy has a dominant role in thermal inactivation of proteins in aqueous solutions (Bromberg et al., 2008). 
According to Anema and Mckenna (1996), the positive values of entropy $\left(\Delta S^{\#}\right)$ for the hydrolysis reaction of carboxymethylcellulose indicate that the reaction proceeds with less speed and is characterized by low regularity. Small changes in the values of $\Delta \mathrm{S}^{\#}$ indicates a preferential destruction of weak bonds (hydrogen and electrostatic), resulting in a lower loss of catalytic activity. The positive values for change in $\Delta \mathrm{S}^{\#}$ also indicate that there are no significant processes of aggregation for carboxylmethylcellulase.
Furthermore, the high values obtained for $\Delta S^{\#}$ variation probably reflect an increased disorder of the active site or the structure of cellulase, which is the main driving force of heat denaturation (D'amico et al., 2003). The cellulase GS-CX from salivary glands of Macrotermes subhyalinus little soldier studied here therefore involves a structurally robust but temperature-sensitive enzymatic system, whose thermal denaturation is mainly under entropic control.

Table 3: Thermodynamic parameters for the Thermal Inactivation of cellulase from salivary glands of Macrotermes subhyalinus little soldier at different Temperatures

\begin{tabular}{cccc}
\hline Temperature $\left({ }^{\circ} \mathrm{C}\right)$ & \multicolumn{3}{c}{ Thermodynamic parameters } \\
\cline { 2 - 4 } & $\Delta \mathrm{H}^{\#}(\mathrm{~kJ} / \mathrm{mol})$ & $\Delta \mathrm{S}^{\#}\left(\mathrm{~J} \mathrm{~mol}^{-1} \mathrm{~K}^{-1}\right)$ & $\Delta \mathrm{G}^{\#}(\mathrm{~kJ} / \mathrm{mol})$ \\
\hline 50 & $113.13 \pm 0.6^{\mathrm{a}}$ & $126.23 \pm 1.6$ & $72.33 \pm 0.3$ \\
55 & $113.08 \pm 0.5$ & $126.10 \pm 1.7$ & $71.70 \pm 0.4$ \\
60 & $113.04 \pm 0.6$ & $125.98 \pm 0.3$ & $71.07 \pm 0.1$ \\
65 & $113.00 \pm 0.4$ & $125.85 \pm 0.6$ & $70.44 \pm 0.1$ \\
Mean & $113.06 \pm 0.5$ & $126.04 \pm 0.4$ & $71.39 \pm 0.3$ \\
\hline
\end{tabular}

${ }^{a}$ Mean $( \pm \mathrm{SD})$ for triplicate experiments

\section{Conclusion}

The results of this study reveals that thermal inactivation of cellulase (GS-CX) from salivary glands of Macrotermes subhyalinus little soldier could be described by a first-order kinetic model. The D-, Z-, k-values, indicate that GS-CX is heat stable and then could be utilized in pasteurization conditions, maintaining part of their biological activity. The high values obtained for activation energy (Ea) and change in enthalpy $(\Delta \mathrm{H} \#)$ indicated that a high amount of energy was needed to initiate denaturation of this carboxylmethylcellulase, most likely due to its stable molecular conformation. Therefore, cellulase involves a structurally robust but temperature-sensitive enzymatic system, whose thermal denaturation is mainly under entropic control.

\section{References}

1. Abdul S., J., T. 2015. Investigation in kinetic-thermodynamic parameters of free cellulase produced by local fungi trichoderma viride. World Journal of Pharmacy and Pharceutical Sciences, 4(2), 1-6

2. Awuah, G. B., Ramaswamy, H. S. Economides, A. 2007. Thermal processing and quality: Principles and overview. Chem. Eng. Proc., 46, 584-602. DOI: 10.1016/j.cep.2006.08.004

3. Barrett, N. E., Grandison, A. S., \& Lewis, M. J. (1999) Contribution of the lactoperoxidase system to the keeping quality of pasteurized milk. Journal of Dairy Research, 66(1), 73-80. DOI:10.1017/s0022029998003252

4. Björck L (1992). Indigenous enzyme sinmilk. Lactoperoxidase.In:FoxF,editor. Advanceddairychemistry. 1.Proteins. London: Elsevier. p. 323-38.

5. Breznak, J. A., \& Brune, A. (1994). Role of microorganisms in the digestion of lignocellulose by termites. Annu. Rev.
Entomol., 39 , $453-487$

Doi.org/10.1146/annurev.en.39.010194.002321

6. Bromberg, A.; Marx, S.; Frishman, G. 2008. Kinetic study of the thermal inactivation of cholinesterase enzymes immobilized in solid matrices. Biochim. Biophys, 1784, 961 966. DOI:10.1016/j.bbapap.2008.02.018

7. Brune, A., \& Stingl, U. (2005). Prokaryotic symbionts of termite gut flagellates: phylogenetic and metabolic implications of a tripartite symbiosis. In Molecular basis of symbiosis (pp. 39-60). Springer Berlin Heidelberg.

8. Chakraborty, N., Sarkar, G. M., \& Lahiri, S. C. (2000) Cellulose degrading capabilities of cellulolytic bacteria isolated from the intestinal fluids of the silver cricket. Environmentalist, 20(1), 9-11.

9. Chutintrasri B, Noomhorm A (2006). Thermal inactivation of polyphenoloxidase in pineapple puree. LebensmittelWissenschaft, 39: 492 - 495. DOI: 10.1016/j.1wt.2005.04.006

10. Clarke A.J. (1997). Biodegradation of Cellulose: Enzymology and Biotechnology. Technomic Pub. Co. Lancaster, PA. pp. 3-68.

11. D'Amico, S., Marx, J.-C., Gerday, C., \& Feller, G. (2003). Activity-stability relationships in extremophilic enzymes. Journal of Biological Chemistry, 278(10), 7891-7896. DOI:10.1074/jbc.M212508200

12. Dogan M, Alkan M, Onganer Y (2000). Adsorption of methlene blue from aqueous solution onto perlite. Water, Air and Soil Pollution, 120: 229-248.

13. Dogan M, Arslan O, Dogan S (2002). Substrate specificity, heat inactivation and inhibition of polyphenol oxidase from different aubergine cultivars. Int. J. Food Sci. Technol., 37: 415-423. Doi.org/10.1046/j.1365-2621.2002.00580.x

14. Dogan N. and Tari C. 2008. "Characterization of three-phase par- titioned exo-polygalacturonase from Aspergillus sojae with unique properties," Biochemical Engineering Journal, 39(1): 43-50. DOI: 10.1016/j.bej.2007.08.008

15. Elba P.S., Maria A.F. (2007). Bioethanol production via enzymatic hydrolysis of cellulosic biomass. Published in 'The role of agricultural biotechnologies for production of bioenergy in developing countries an FAO seminar held in Rome. Available: http:// www.fao.org/biotech/seminaroct 2007.htm.

16. Espachs-Barroso, A., Van Loey, A., Hendrickx, M., \& 
Martín-Belloso, O. (2006). Inactivation of plant pectin methylesterase by thermal or high intensity pulsed electric field treatments. Innovative Food Science \& Emerging Technologies, 7(1), 40-48. Doi.org/10.1016/j.ifset.2005.07.002

17. Fagbohoun, J. B., Ahi, A. P., Karamoko, Y., Dabonné, S., Kouadio, E. J. P., \& Kouamé, L. P. (2012). An endo-beta-Dglycosidase from salivary glands of Macrotermes subhyalinus little soldier with a dual activity against carboxymethylcellulose and xylan. International Journal of Biosciences, 2, 1-10.

18. Galani D, Owusu ARK (1997). The comparative heat stability of bovine B-lactoglobulin in buffer and complex media. J. of Sci. and Food Agric., 74: 89-98.

19. Giannakopoulou A., Patila M., Spyrou K., Chalmpes N., Zarafeta D., Skretas G., Gournis D. and Stamatis H. (2019). Development of a Four-Enzyme Magnetic Nanobiocatalyst for Multi-Step Cascade Reactions. Catalysts, 995, 1-22. doi:10.3390/catal9120995

20. Gnangui SN, Niamke SL, Kouame LP (2009). Some characteristics of polyphenoloxidase purified from edible yam (Dioscorea cayenensisrotundata cv. Longbô) cultivated in Côte d'Ivoire. J. of Food Sci. and Technol., 44: 2005-2012.

21. Guiavarc'h, Y. P., Deli, V., Van Loey, A. M., \& Hendrickx, M. E. (2002). Development of an enzymic time temperature integrator for sterilization processes based on Bacillus licheniformis $\alpha$-amylase at reduced water content. Journal of Food Science, 67(1), 285-291. doi.org/10.1111/j.13652621.2002.tb11399.x

22. Haloi D. J, Borkotoki A, Mahanta R, Haloi I. H. 2012. Cellulase Activity and Kinetics in Rice Grasshopper Hieroglyphus banian (Orthoptera: acrididae). Indian Journal of Science an Technology, 5(12): 3753-3757.

23. Hill J., Nelson E., Tilman D., Polasky S. and Tiffany D. (2006). Environmental, economic, and energetic costs and benefits of biodiesel and ethanol biofuels. Proc Natl Acad Sci USA. 314:1598-1600. DOI:10.1073/pnas.0604600103

24. Hong, Y., Dashtban, M., Chen, S., Song, R., \& Qin, W. (2012). Enzyme production and lignin degradation by four basidiomycetous fungi in submerged fermentation of peat containing medium. International Journal of Biology, 4, 172180. DOI:10.5539/ijb.v4n1p172

25. Inoue, T., Murashima, K., Azuma, J. L., Sugimoto, A., \& Slaytor, M. (1997). Cellulose and xylan utilization in the lower termite Reticulitermes speratus. J. Insect Physiol., 43, 235-242. DOI:10.1016/s0022-1910(96)00097-2

26. Kouamé L. P., Kouamé A. F., Niamké S. L., Faulet M. B. \& Kamenan A. (2005). Biochemical and catalytic properties of two $\beta$-glycosidases purified from workers of the termite Macrotermes subhyalinus (Isoptera: Termitidae). International Journal Tropical Insect Sciences. 25: 103-113. DOI: https://doi.org/10.1079/IJT2006106

27. Longo, M. A.; Combes, D. 1999. Thermostability of modified enzymes -a detailed study. J. Chem. Technol. Biotechnol, 74,25-32.

28. Lowry OH., Rosebrough NJ, Farr AL, Randall RJ (1951) Protein measurement with the folin phenol reagent. J. of Biol. and Chem., 193: 265-275.

29. Lu, W. J., Wang, H. T., \& Nie, Y. F. (2004). Effect of inoculating flower stalks and vegetable waste with lignocellulolytic microorganisms on the composting process. Journal of Environmental Science and Health, Part B, 39(56), 871-887.

30. Lynd L.R., Van Zyl W.H., McBride J.E., Laser M. (2005). Consolidated bioprocessing of cellulosic biomass: an update. Curr Opin Biotechnol. 16(5):577-583. DOI:10.1016/j.copbio.2005.08.009

31. Marín, E., Sánchez, L., Pérez, M. D., Puyol, P., and Calvo, M. (2003). Effect of heat treatment on bovine lactoperoxidase activity in skim milk: kinetic and thermodynamic analysis. Journal of Food Science, 68(1), 89-93.
32. Doi.org/10.1111/j.1365-2621.2003.tb14120.x

33. Martin N. 2010. Purificaçao e Caracterizaçao da Poligalacturonase Termoestavel Produzida pela Linhagem Fungica Thermomucor Indicae-Seudaticae N31 em Fermentaçao em Estado Solido e Submersa, UNESP, Rio Claro, Brazil.

34. Matsumoto, M., Kida, K., \& Kondo, K. (1997). Effects of polyols and organic solvents on thermostability of lipase. Journal of Chemical Technology \& Biotechnology, 70(2), 188-192.https://doi.org/10.1002/(SICI)10974660(199710)70:2<188::AID JCTB745>3.0.CO;2-X

35. Mswaka, A. Y., and Magan, N. (1998). Wood degradation, and cellulase and ligninase production, by Trametes and other wood-inhabiting basidiomycetes from indigenous forests of Zimbabwe. Mycological Study, 102(11), 1399 1404. DOI: https://doi.org/10.1017/S0953756298006789

36. Nutt, A., Sild, V., Prtterson, G., and Johansson, G. (1998). Progress curve as a means for functional classification of cellulases, Europian Journal of Biochemistry, 258, 200

37. Rouland, C., Civas, A., Renox, J., and Petek, F. (1988) Purification and Properties of Cellulases from the termite Macrotermes mulleri (Termitidae, Macrotermitinae) and its symbiotic fungus Termitomyces sp. Comp. Biochem. Physiol., 91B(3), 449-458.

38. Saqib A. A. N., Hassan M., Khan N. F. and Baig S. 2010 "Thermostability of crude endoglucanase from Aspergillus fumigatus grown under solid state fermentation (SSF) and submerged fermentation $(\mathrm{SmF}), "$ Process Biochemistry, 45(5): 641- 646. DOI: 10.1016/j.procbio.2009.12.011

39. Slaytor, M. (2000). Energy metabolism in the termite and its gut microbiota. In Termites: Evolution, Sociality, Symbioses, Ecology (pp. 307-332). Springer Netherlands.

40. Slaytor, M. (1992). Cellulose digestion in termites and cockroaches: what role do symbionts play? Comp. Biochem. Physiol. B., 103, 775-784. https://doi.org/10.1016/03050491(92)90194-V

41. Sousa, R. (1995). Use of glycerol, polyols and other protein structure stabilizing agents in protein crystallization. Acta Crystallographica Section D, 51, 271-277. https://doi.org/10.1107/S0907444994014009

42. Stumbo, C. R. (1973). Thermobacteriology in food processing (2nd ed., p. 336). New York, NY: Academic Press. Tayefi-Nasrabadi, H., \& Asadpour, R. (2008). Effect of heat treatment on buffalo (Bubalus bubalis) lactoperoxidase activity in raw milk. Journal of Biology Science, 8(8), 1310-1315.

43. Tabatabai M.A. (1982). Soil enzymes.In: Page, AL, Miller RH, Keeney DR. (Eds.), Methods of Soil Analysis. Part 2. Chemical and microbiological properties. 2nd ed. American Society of AgronomySoil Science Society of America, Madison, WI, pp. 903-947.

44. Trindade L.V., Desagiacomo C., Polizeli M. de L. T. de M. André Ricardo de Lima Damasio A.R de L., Lima A.M.F., Gomes E. and Bonilla-Rodriguez G.O. 2016. Biochemical Characterization, Thermal Stability, and Partial Sequence of a Novel Exo-Polygalacturonase from the Thermophilic Fungus Rhizomucor pusillus A13.36 Obtained by Submerged Cultivation. BioMed Research International, ID 8653583, 10 pages Doi.org/10.1155/2016/8653583

45. Vaithanomsat, P., Chuichulcherm, S., and Apiwatanapiwat, W. (2009). Bioethanol production from enzymatically saccharified sunflower stalks using steam explosion as pretreatment, Proceedings of World Academy of Science, Engineering and Technology, 37, 140-143. doi=10.1.1.193.1882\&rep=rep1\&type $=$ pdf

46. Waliszewski, K. N.; M'rquez, O.; Pardio, V. T. 2009. Quantification and characterisation of polyphenol oxidase from vanilla bean. Food Chem. 2009, 117, 196-203.

47. Zhou H, Feng X. (1991). Polyphenol oxidase from Yali pear (Pyrusbretschneideri). J. of the Sci. of Food and Agric., 57: 307-313. https://doi.org/10.1002/jsfa.2740570302 